\title{
VARIABILITY AND TRENDS OF PRECIPITATION ON LOW- AND HIGH-ALTITUDE STATIONS IN SERBIA
}

\author{
Igor Leščešen ${ }^{A}$, Dragan Milošević ${ }^{A}$, Rastislav Stojsavljević ${ }^{B}$ \\ Received: February 2, 2021 | Accepted: June 28, 2021 \\ DOI: 10.5937/ZbDght2101014L
}

\begin{abstract}
For the trend analysis of theannual, seasonal and monthly precipitation linear regression and Mann-Kendall (MK) tests at the 5\% significance level were applied. In this study, precipitation data from two stations in Serbia for the 1949-2019 period were used. Results indicate that increasing trends of precipitation for the selected station can be observed but these trends were not statistically significant according to MK test. Then again, MK test has shown that only on Palić station during autumn precipitations have statistically significant increase during the observed period with a $p$ value of 0.0441 at the significant level $p=0.005$.
\end{abstract}

Keywords: Precipitation; trend; Serbia; Vlasina; Palić

\section{INTRODUCTION}

Current climate change has caused the study of many precipitation characteristics, such as precipitation amounts (Dai et al., 1997; New et al., 2001; Smith et al., 2012; Becker et al., 2013;Hynčica et al., 2019), precipitation extremes (Frich et al., 2002; Allan, Soden, 2008; van den Besselaar et al., 2013; Villarini et al., 2013; O'Gorman, 2015) and precipitation intensity (e.g., Brunetti et al., 2000; Maraun et al., 2008; Berg et al., 2013; Cioffi et al., 2015; Ye et al., 2016).

Nguyen et al. (2018) observed a global increasing trend in precipitation. However, there are regional variations that do not follow global trends (Gocić, Trajković, 2013). During the 20thcentury, precipitation decreased over southern parts of Europe, Africa and Asia (Spinoni et al., 2017). Over some regions, mainly North Africa, north Italy and some parts of Iberian Peninsula anincreasing trend of precipitation is observed (Philandras, 2011; Brunnetti et al., 2001). Annual and monthly precipitation patterns over the East and Central Europe was examined by Niedźwiedź et al. (2009). Regarding other parts of the European continent, annual rainfall shows that every decade since 1960 an increasing trend of $70 \mathrm{~mm}$ is observedover Northern and Western Europe. In contrast, over Southern Europe a decrease of $90 \mathrm{~mm}$ per decade has been observed (European Environment Agency [EEA], 2017).

Several studies from different countries on Balkan Peninsula has considered precipitationsas an indicator of climate change, e.g. Montenegro (Burić et al., 2018a; Burić et al., 2018b; Burić, Doderović, 2019), Bosnia and

A Climatological and Hydrological Research Center, University of Novi Sad, Serbia; corresponding author, e-mail: igorlescesen@yahoo.com

B Department of Geography, Tourism and Hotel Management, Faculty of Sciences, University of Novi Sad, Serbia 
Herzegovina (Popov et al., 2019), Slovenia (Tošić et al., 2016; Milošević et al., 2016) Croatia (Gajić-Čapka et al., 2015), Greece (Markonis et al., 2017), and Bulgaria (Alexandrov et al., 2004; Nikolova, 2004; Radeva, Nikolova, 2020). Precipitation variability and trends were the subject of many studies worldwide (Oguntunde et al., 2011; Tabari, Hosseinzadeh Talaee, 2011; Libanda et al., 2017;Kingúza, Tilwebwa, 2019; Ghaedi, Shojaiean, 2020) as well as in Serbia. For instance, Tosic (2004) investigated spatial and temporal variability of summer and winter precipitation for the period of 50 years at 30 stations. Milovanović (2005) analyzed precipitation over Stara planina mountain in southeast part of Serbia. Several authors investigated precipitation variability and trends in Belgrade (Tosic and Unkasevic, 2005; Djordjevic, 2008), while Savić et al. (2020) investigated the precipitation variability in Novi Sad. Furthermore, Unkasevic and Tosic (2011) examined the daily precipitation over Serbia for the 1949-2007 period. Milošević and Savić (2013) investigated precipitation changes in the Pannonian and Peripannonian parts of Serbia, as well as the effects of changes in precipitation and temperature on the crop yield variability in the Autonomous Province of Vojvodina (Milošević et al., 2015). Precipitation trends over Serbia show only weak and mostly nonsignificant trends according to the results presented by Luković et al. (2013). Milentijević et al. (2020) analyzed precipitation trends in Mačva district.

This study examines the precipitation amounts and trends registeredon two meteorological stations with substantially different altitudes: Palić $(102 \mathrm{~m})$ and Vlasina $(1254 \mathrm{~m})$. Analyzed period covers 71 years from 1949 to 2019, which is the longest available dataset. Precipitation trends per seasons were also analyzed. With this study, the aim is to contribute to the increased understanding of precipitation variability on different low and high altitudeareas in Serbia.

\section{STUDY AREA}

The study area is located in Serbia that occupies the central part of the Balkan Peninsula. The area of Serbia is $88.499 \mathrm{~km}^{2}$. Central and southern regions of the country are made up ofmountains and highlands, while in the north vast and mainly flat Pannonian plain is located. Climate of the country is characterized as temperate continental climate with four seasons (Gocić, Trajković, 2013).The geographical information of the investigated stations is listed in Table 1. Selection criteria for these stations were as follows: (1) good quality datasets; (2) availability and reliability of the data; (3) the data should have sufficientrecord length; and (4) each station has to be located near a major lake.

Table 1. Geographical information about investigated stations

\begin{tabular}{|l|c|c|c|}
\hline Meteorological station & Latitude $(\phi)$ & Longitude $(\lambda)$ & Altitude $(m)$ \\
\hline Palić & $46^{\circ} 06^{\prime} \mathrm{N}$ & $19^{\circ} 46^{\prime} \mathrm{E}$ & 102 \\
\hline Vlasina & $42^{\circ} 45^{\prime} \mathrm{N}$ & $22^{\circ} 20^{\prime} \mathrm{E}$ & 1254 \\
\hline
\end{tabular}

\section{DATA AND METHODOLOGY}

This study analyzes monthly and annual precipitation sums for two stations in the period 1949-2019. Data from two meteorological stationswere taken from the Republic Hydrometeorological Service of Serbia (http:// www.hidmet.gov.rs/).

Precipitation trends were processed using two statistical approaches as suggested by Gavrilov et al., 2016; Milentijević et al., 2020) the trend equation was determined for each station and the statistical significance of trend was analyzed byapplying a non-parametric Mann-Kendall (MK) test.The trend equation procedure is based on determining the slope size of the precipitation data in the trend equation. Three scenarios are proba- 
ble: a) the trend is positive - when the slope size is greater than zero; b) the trend is negative - when the slope size is less than zero and c) there is no trend - when slope equals zero. For the second statistical procedure the non-parametric Mann-Kendall (MK) test was applied (Mann 1945, Kendall 1970). This test is the most extensively used at-site test for determining trend significance (Bocheva et al., 2009; Kysely' , 2009; Sadri et al., 2009; Korhonen, Kuusisto, 2010; Petrow, Merz, 2009; Petrow et al., 2009; Bormann et al., 2011; Meilutyte-Barauskiene et al., 2010; Blöschl et al., 2012; Giuntoli et al., 2012). The main advantage of MK test is that it is a robust, rank-based test that, in contrast to the regular Student's t-test, is not to be determined by the statistical distribution of the parameter that is analyzed (Schmidli, Frei 2005). For trend significance a weaker criteria were applied dueto the high variability in precipitation (Hänsel 2009, Łupikasza et al. 2017). MK test was applied to test two hypotheses were tested: $\mathrm{H}_{0}$ (null hypothesis) that indicates that there is no trend in data series; and the $\mathrm{H}_{0}$ hypothesis that indicates that there is a statistically significant trend in data series, at the selected level of significance ( $\alpha$ ). The level of significance in the hypothesis was determined by calculating probability (p). Significance levelawas set at 0.05. For analyzing the data, a Microsoft Office Excel 2007 software and its XLSTAT extension (https://www.xlstat.com/en) were used.

For the filling of the missing data two methods were used. First, we used the interpolation method that was applied if a station had five or less consecutivemonths of missing data. Extrapolation was implemented as the second method if a station had six or more consecutive months of missing data (Savić et al., 2010). Arithmetic mean was applied for the first method, while for the second method firstly Person product moment correlation coefficient was performed and then arithmetic mean (Stojsavljević et al., 2013). Extrapolation for the Vlasina station was conducted by using data from the neighboring stations that are presented in table 2.

Table 2. Geographical information about meteorological stations used for extrapolation

\begin{tabular}{|l|c|c|c|c|}
\hline Meteorological station & Latitude $(\phi)$ & Longitude $(\lambda)$ & Altitude $(\mathrm{m})$ & Distance from Vlasina $(\mathrm{km})^{*}$ \\
\hline Babušnica & $43^{\circ} 04^{\prime} \mathrm{N}$ & $22^{\circ} 25^{\prime} \mathrm{E}$ & 520 & 73 \\
\hline Predejane & $42^{\circ} 50^{\prime} \mathrm{N}$ & $22^{\circ} 08^{\prime} \mathrm{E}$ & 311 & 38 \\
\hline Kukavica & $42^{\circ} 47^{\prime} \mathrm{N}$ & $21^{\circ} 57^{\prime} \mathrm{E}$ & 1438 & 64 \\
\hline
\end{tabular}

*All distances are calculated using software Google Earth

Pearson's correlation moment for correlative cells was used for extrapolation Pearson's correlation moment: maximum correlation 1, minimum 0 minimum correlation is 0.5 all three correlative cells meet the conditions Babusnica 0.76, Predejane 0.77, Kukavica 0.62.

For defining the seasons we used interpretation suggested by Milošević et al, (2016) and Leščešen et al. (2020) where seasons are defined as follows: winter (December - January - February), spring (March - April - May), summer (June - July - August) and autumn (September - October - November). Regarding the winter season, it is important to highlight that precipitation amount corresponds to January-February of the calendar year and to December of the previous year.

\section{RESULTS AND DISCUSSION}

For two time series covered in this study both linear trend and MK test were calculated. The analysis was complemented with calculation of precipitation change per decade and trend probability for both time series from the investigated stations. Obtained results are presented in figurel and table 3.

Total annual amount of precipitation on investigated stations during observed period was $560.5 \mathrm{~mm}$ on Palić and $837.1 \mathrm{~mm}$ on Vlasina station. This indicates that on every $100 \mathrm{~m}$ altitude increase amount of precipitation rises by $24 \mathrm{~mm}$. This result is also confirmed by the result presented by Gocić and Trajković (2013b). 

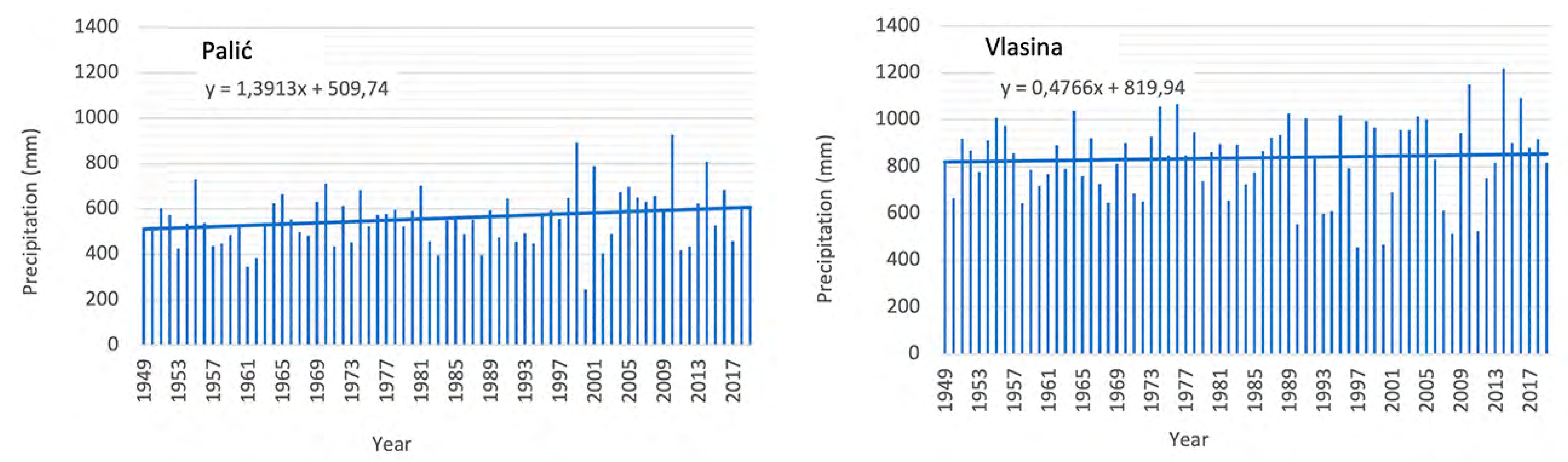

Figure 1. Linear trend of annual sums of precipitations on selected stations

Table 3. Change per decade and reliability probability for average annual precipitation at selected stations

\begin{tabular}{|l|c|c|}
\hline Meteorological station & Change per decade $(\mathrm{mm})$ & $\mathrm{P}(\%)$ \\
\hline Palić & $-13,93$ & 0.0586 \\
\hline Vlasina & +4.76 & 0.1679 \\
\hline
\end{tabular}

*Trend equations are presented in figure 1.

Figure 1 and table 3 show that the trend equations for the Palic station is positive, presented result is in good accordance with conclusions made by Unkašević et al (2011) and Stojanović (2012). To further check these results, MK test was applied. Because the probabilities p are bigger than the significance level, $\alpha=5 \%$, the null hypothesis cannot be excluded in this case. The risk of excluding the null hypothesis while it is true is $5.86 \%$. Regarding Vlasina station, figurel and table 3 show a slightly positive trend, but MK trend has shown that this trend is not statistically significant at the $\alpha=5 \%$ because the risk of excluding the null hypothesis while it is true is $16.79 \%$. Results presented by Gocić and Trajković (2013) conclude that there is no statistically significant trend in the annual amount of precipitation at most stations in Serbia.

Table 4. Change per decade and reliability probability for average seasonal precipitation at selected stations

\begin{tabular}{|l|c|c|c|c|}
\hline \multirow{2}{*}{ Period of the year } & \multicolumn{2}{|c|}{ Palić } & \multicolumn{2}{c|}{ Vlasina } \\
\cline { 2 - 5 } & Change per decade $(\mathrm{mm})$ & $\mathrm{P}(\%)$ & Change per decade $(\mathrm{mm})$ & $\mathrm{P}(\%)$ \\
\hline Winter & 0,38 & 0.7765 & 0,94 & 0.5196 \\
\hline Spring & 1,47 & 0.1996 & 2,4 & 0.1005 \\
\hline Summer & 1,26 & 0.2870 & $-0,69$ & 0.7571 \\
\hline Autumn & 1,69 & $0.0441^{*}$ & 1,05 & 0.6518 \\
\hline
\end{tabular}

* Trend equations are presented in FIGURE 3.

Seasonal amount of precipitation is highest during spring with $44.4 \mathrm{~mm}$ on Palić and $79.7 \mathrm{~mm}$ on Vlasina station, while the lowest amount of precipitation is recorded during winter with $37.5 \mathrm{~mm}$ on Palić and $65.6 \mathrm{~mm}$ on Vlasina station. At $100 \mathrm{~m}$ elevation the amount of precipitation increases by $2.39 \mathrm{~mm}$ during winter, $3.14 \mathrm{~mm}$ in spring, $1.1 \mathrm{~mm}$ in summer and $2.04 \mathrm{~mm}$ during autumn. Explanation for this is provided by Tošić and Unkašević (2013) where it is stated that this is in direct association with the intensive convection of humid and cold air masses.

Figure 2 and table 4 show that the trend equations and $\mathrm{p}$ value of precipitations per seasons. At the Palić station it is noticeable that according to the trend equation that the precipitation trend is positive and increasing over colder period of the year (winter and autumn). These results are in good agreement with the results presented by Gocić and Trajković (2013b) that show that, at the seasonal level, a positive trend is observed during the autumn months. Furthermore, when precipitation trend is Vojvodina were studied by Tošić et al. (2014) a positive trend in precipitation was found bot at annual and seasonal level (winter and autumn).Then 

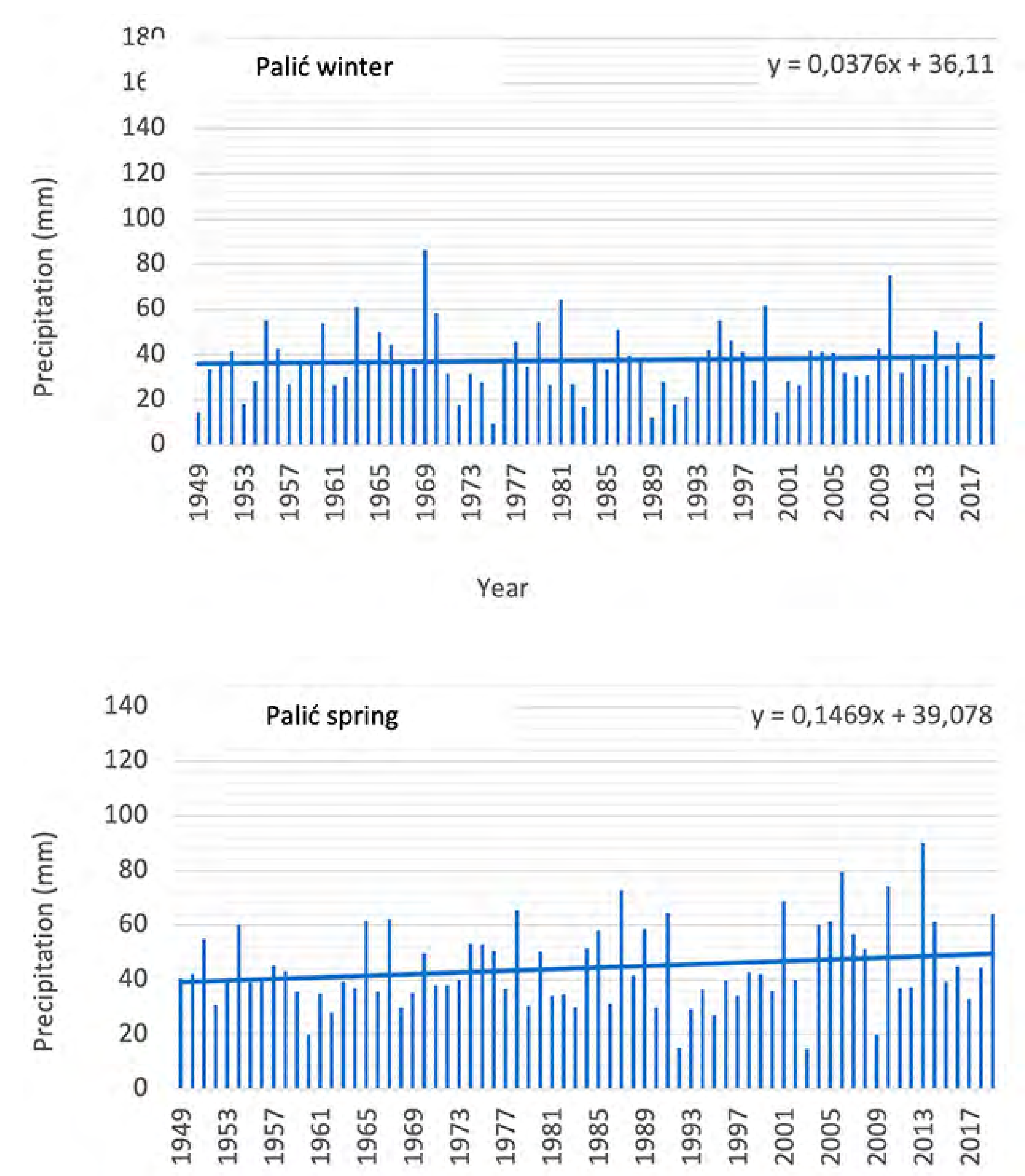

Year

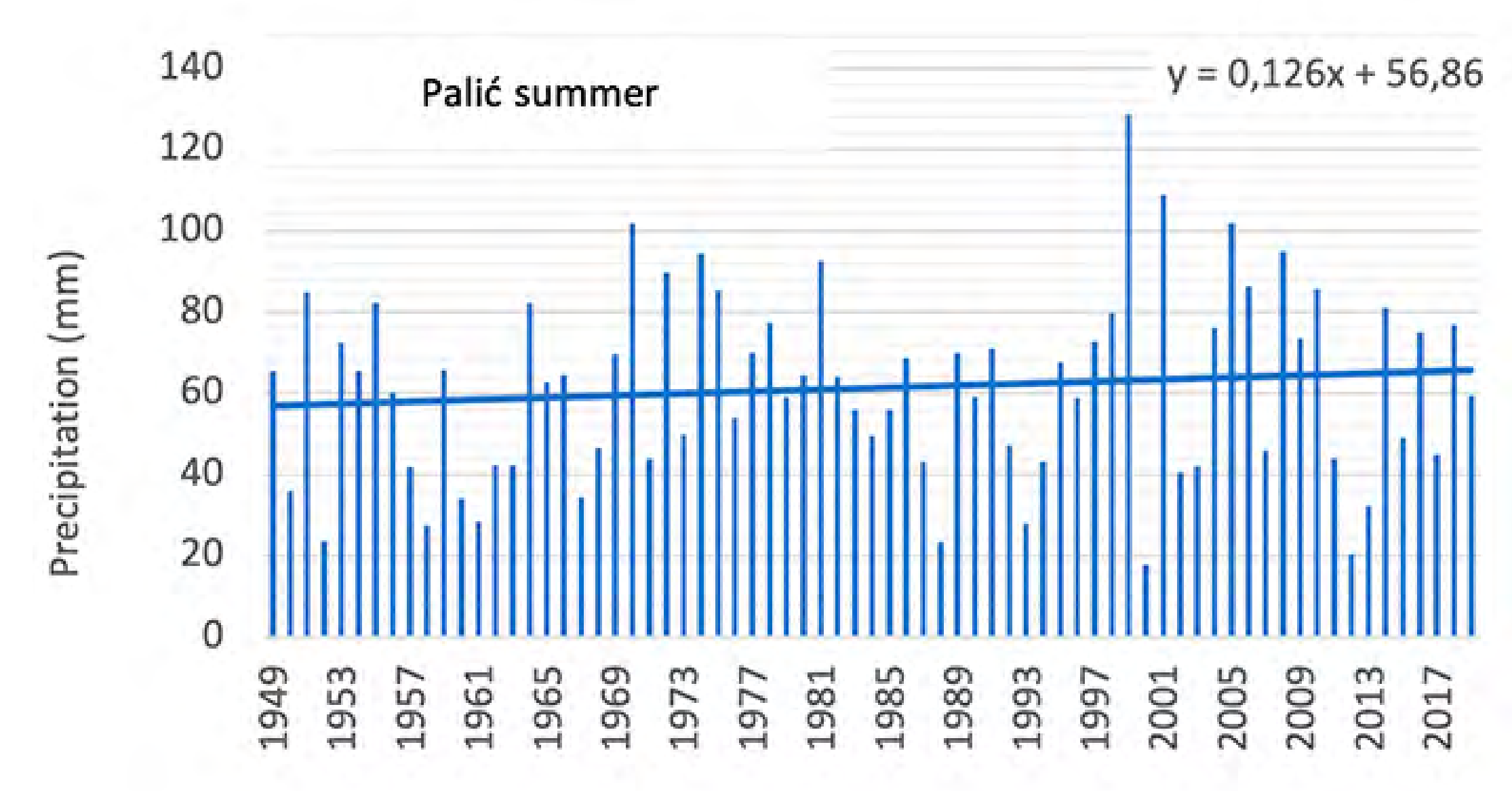

Year

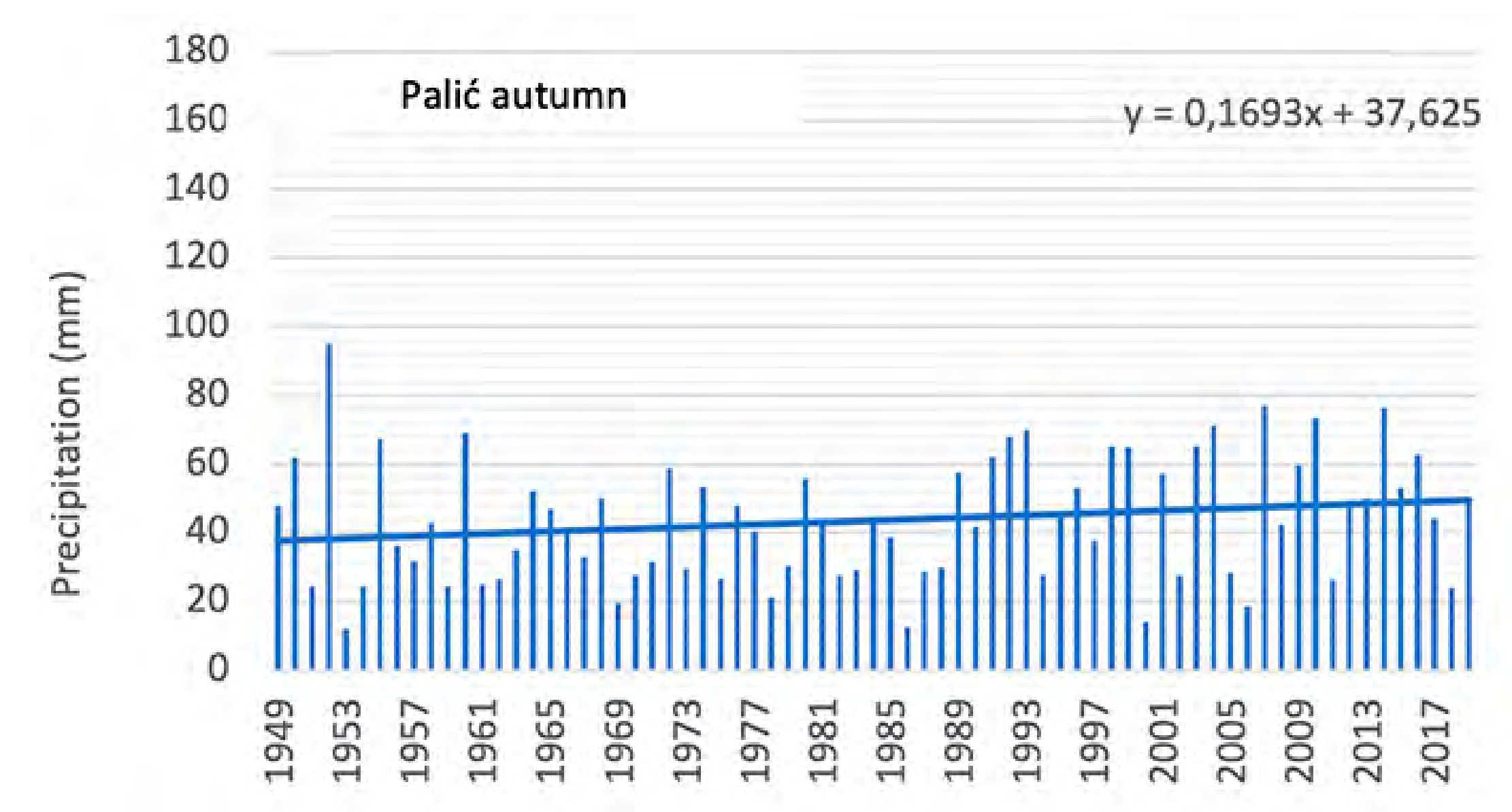

Year
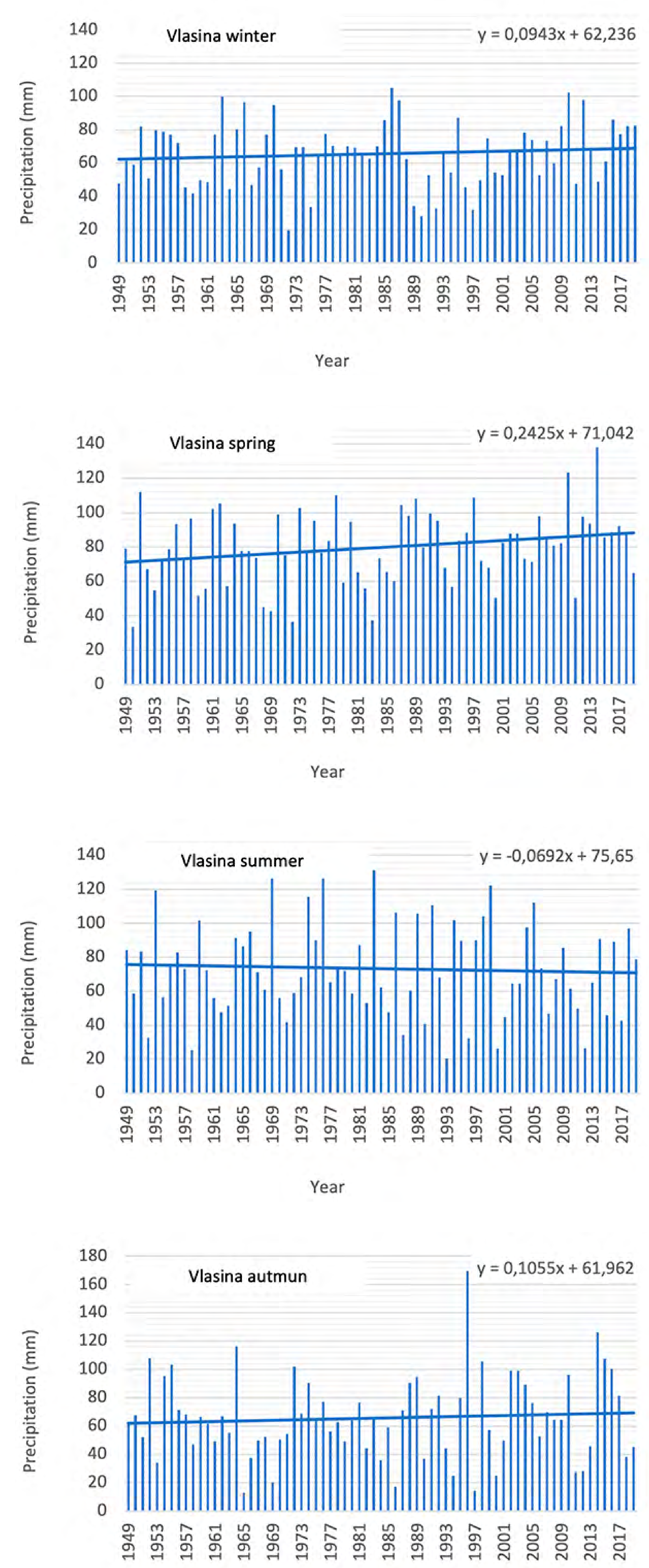

Year

Figure 2. Linear trend of annual sums of precipitations on selected stations 
again, MK test has shown that only autumn precipitations have statistically significant increase during the observed period with a $p$ value of 0.0441 at the significant level $p=0.005$. As the calculated $p$-value is lesser than the significance level alpha $=0.05$, the null hypothesis should be rejected and the alternative hypothesis should be accepted, that is, that there is a trend in the series. During warm period of the year, spring and summer MK test results show that the trend is not statistically significant with p values of 0.1996 and 0.2870 respectively. At the Vlasina station, linear trend equation shows a positive trend over autumn, winter and spring while during summer the trend is negative (Table 3). MK test results for the precipitation at the Vlasina station show that during neither season trend was statistically significant.

Linear trend analysis of the monthly precipitation on Palić station show that April, July, November and December had negative trend of precipitation but based on the MK test these trends were not statistically significant $(0.5164,0.2457,0.2625$ respectively). During other months' linear trend showed positive increase of precipitation but according MK test this positive trend is statistically significant in the months of September and October, 0.0312 and 0.0452 respectively. Meanwhile, on Vlasina station even thou linear trend equation indicate that there is a positive trend during some months (January, February, April, Jul, October and December) and negative trends during the other months, no statistically significant trend was detected during either month (Table5).

Table 5. Monthly linear trend equation,change per decade $(\mathrm{mm})$ and reliability probability $(\mathrm{p})$ at the selected stations

\begin{tabular}{|c|c|c|c|c|c|c|}
\hline \multirow[t]{2}{*}{ Months } & \multicolumn{3}{|c|}{ Palić } & \multicolumn{3}{|c|}{ Vlasina } \\
\hline & $\begin{array}{c}\text { Linear trend } \\
\text { equation }\end{array}$ & $\begin{array}{c}\text { Change per } \\
\text { decade }(\mathrm{mm})\end{array}$ & $p(\%)$ & $\begin{array}{l}\text { Linear trend } \\
\text { equation }\end{array}$ & $\begin{array}{c}\text { Change per } \\
\text { decade }(\mathrm{mm})\end{array}$ & $\mathrm{p}(\%)$ \\
\hline January & $0.095 x+30.04$ & 0.95 & 0.5565 & $0.1296 x+61.854$ & 1.29 & 0.7053 \\
\hline February & $0.2003 x+26.303$ & 2.00 & 0.3405 & $0.1078 x+56.352$ & 1.08 & 0.7417 \\
\hline March & $0.1855 x+25.561$ & 1.86 & 0.4439 & $0.1875 x+59.194$ & 1.86 & 0.3565 \\
\hline April & $-0.0459 x+43.823$ & 0.45 & 0.5164 & $0.2146 x+71.106$ & 2.15 & 0.4650 \\
\hline May & $0.301 x+47.851$ & 3.01 & 0.1875 & $0.3194 x+82.689$ & 3.19 & 0.1575 \\
\hline June & $0.1989 x+66.757$ & 1.99 & 0.6813 & $-0.3307 x+112.21$ & -3.31 & 0.4202 \\
\hline July & $-0.0043 x+60.08$ & -0.04 & 0.6446 & $0.1752 x+61.38$ & 1.75 & 0.4000 \\
\hline August & $0.1833 x+43.742$ & 1.83 & 0.1557 & $-0.0521 x+53.354$ & -0.52 & 0.8195 \\
\hline September & $0.4278 x+29.387$ & 4.28 & 0.0315 & $0.2455 x+51.777$ & 2.46 & 0.3777 \\
\hline October & $0.3378 x+25.966$ & 3.38 & 0.0452 & $0.3333 x+52.831$ & 3.33 & 0.9482 \\
\hline November & $-0.2699 x+57.704$ & -2.69 & 0.2457 & $-0.2646 x+83.754$ & -2.65 & 0.4583 \\
\hline December & $-0.1824 x+51.985$ & -1.82 & 0.2625 & $0.088 x+68.318$ & 0.88 & 0.7693 \\
\hline
\end{tabular}

Precipitation analysis on monthly level suggests that on both stations a decreasing trend was observed in November, while both decreasing and increasing trends were observed in other months. Similar results were presented by Gocić and Trajković (2013a). Average monthly amount of precipitation on Palić station is lowest during March, which is in agreementwith the results presented by Unkašević et al (2011). The spatial distribution of average annual precipitation indicates that it increases with the altitude (Gocić et al 2013), that is clearly noticeable in figure 2 .

\section{CONCLUSION}

In this study determination of the monthly, seasonal and annual precipitation trends at stations with different altitudes in the period from 1949to 2019 was conducted. For this purpose, precipitation data from Palić and Vlasina meteorological stations were analyzed by applying both analysis of linear trends and the MannKendall test. Results obtained provide no definitive conclusion. Even thou positive linear trend is detected on 
most time scales (annual, seasonal and monthly), according to the MK test only during autumn this trend was statistically significant $(\mathrm{p}=0.441)$ and only on Palić station. On monthly scale, statistically significant trend was detected during September and October with a p value of 0.0315 and 0.0452 respectively. Regarding Vlasina station, no statistically significant trend has been detected on any time scale. Results presented in this study are in good accordance with global precipitation trends, yet, precipitations over Southeastern Europe have decreased. For that purpose, further research of precipitation distributions, trends and tendencies is necessary in order to define probable reasonsfor these phenomena. This paper provides solid basis for the future research as it offersperceptions into the precipitation dynamic over the past several decades and the differences that altitude makes in the precipitation trends.

\section{REFERENCES}

Alexandrov, V., Schneider, M., Koleva, E., Moisselin, J-M. (2004). Climate variability and change in Bulgaria during the 20th century. Theor. Appl. Climatol. 79, 133-149. DOI 10.1007/s00704-004-0073-4.

Allan, R.P.,Soden, B.J.(2008). Atmospheric warming and the amplification of precipitation extremes. Science, 321, 1481-1484. https://doi.org/10.1126/science.1160787.

Becker, A., Finger, P., Meyer-Christoffer, A., Rudolf, B., Schamm, K., Schneider, U.,Ziese, M.(2013). A description of the global land-surface precipitation data products of the Global Precipitation Climatology Centre with sample applications including centennial (trend) analysis from 1901-present. Earth Syst. Sci. Data, 5, 71-99. https://doi.org/10.5194/essd-5-71-2013.

Berg, P., Moseley, C.H., Haerter, J.O.(2013). Strong increase in convective precipitation in response to higher temperatures. Nat. Geosci., 6, 181-185. https://doi.org/10.1038/ngeo1731.

Brunetti, M., Buffoni, L., Maugeri, M., Nanni, T.(2000). Precipitation intensity trends in northern Italy. Int. J. Climatol., 20, 1017-1031. https://doi.org/10.1002/1097-0088.

Brunetti, M., Maugeri, M., Nanni, T. (2001). Changes in total precipitation, rainy days and extreme events in northeastern Italy, Int. J. Climatol., 21, 861-871.

Burić, B. D., Dragojlović, M. J., Milenković, M., Popović, Z. Lj., Doderović, M. M. (2018a). Influence of variability of the East Atlantic Oscillation on the air temperature in Montenegro. Thermal Science, 22(1B), 759766.

Burić, D., Doderović, M.(2019). Precipitation, humidity and cloudiness in Podgorica (Montenegro) during the period 1951-2018. Geographica Pannonica, 23(4), 233-244.

Burić, D., Ducić, V., Mihajlović, J. (2018b). Relationship between mean annual temperatures and precipitation sums in Montenegro between 1951-1980 and 1981-2010 periods. Bulletin of the Serbian Geographical Society, 98(1), 31-48.

Cioffi, F., Lall, U., Rus, E., Krishnamurthy, C.K.B.(2015). Space-time structure of extreme precipitation in Europe over the last century. Int. J. Climatol. 35, 1749-1760. https://doi.org/10.1002/joc.4116.

Dai, A., Fung, I.Y., Del Genio, A.D.(1997). Surface observed global land precipitation variations during 190088. J. Clim., 10, 2943-2962. https://doi.org/10.1175/1520442(1997)010.

Đorđević, S.V. (2008). Temperature and precipitation trends in Belgrade and indicators of changing extremes for Serbia. Geographica Pannonica, 12(2), 62-68. DOI: 10.5937/GeoPan0802062D.

European Environment Agency (EEA), (2017). Climate change, impacts and vulnerability in Europe 2016, an indicator - based report (EEA Report No. 1/2017). European Environment Agency, Copenhagen.

Frich, P., Alexander, L.V., Della-Marta, P., Gleason, B., Haylock, M., Klein Tank, A.M.G., Peterson, T.(2002). Observed coherent changes in climate extremes during the second half of the twentieth entury. Clim. Res., 19, 193-202. https://doi.org/10.3354/cr019193.

Gajić-Čapka, M., Cindrić, K., Pasarić, Z. (2015). Trends in precipitation indices in Croatia, 1961-2010.Theor Appl Climatol, 121, 167-177 https://doi.org/10.1007/s00704-014-1217-9 
Ghaedi, S., Shojaiean, A. (2020). Spatial and temporal variability of precipitation concentration in Iran. Geographica Pannonica, 24(4), 244-251. doi: 10.5937/gp24-27361

Gocić, M., Trajković, S. (2013a). Spatio-temporal patterns of precipitation in Serbia. Theor Appl Climatol DOI 10.1007/s00704-013-1017-7

Gocić, M.,Trajković, S. (2013b). Analysis of precipitation and drought data in Serbia over the period 19802010. Journal of Hydrology, 494, 32-42. http://dx.doi.org/10.1016/j.jhydrol.2013.04.044

Hänsel, S. (2009).Changes in Saxon precipitation characteristics. Trends of extreme precipitation and droughts. Doctoral dissertation, TU Bergakademie Freiberg, Cuvillier Verlag, Göttingen.

Hynčica, M.,Hutha, R. (2019). Long-term changes in precipitation phase in Europe in cold half year, Atmospheric Research, 227, 79-88. https://doi.org/10.1016/j.atmosres.2019.04.032

Kendall, M.G.(1975).Rank correlation methods. Charles Griffin, London.

Kingúza, P.H.,Tilwebwa, S.L.P.(2019). Inter-annual variability of March to May rainfall over Tanzania and its association with atmospheric circulation anomalies. Geographica Pannonica, 23(3), 147-161.

Leščešen, I., Dolinaj, D., Pantelić, M., Telbisz, T., Varga, G. (2020). Hydrological drought assessment of the Tisza river. J. Geogr. Inst. Cvijic, 70(2), 89-100. https://doi.org/10.2298/IJGI2002089L

Libanda, B., Zheng, M., Banda, N.(2017). Variability of extreme wet events over Malawi. Geographica Pannonica, 21(4), 212-223.

Luković, J., Bajat, B., Blagojević, D., Kilibarda, M. (2013). Spatial pattern of recent rainfall trends in Serbia (1961-2009). Regional Environmental Change, 14(5), 1-11 DOI: 10.1007/s10113-013-0459-x

Łupikasza, B.E. (2017). Seasonal patterns and consistency of extreme precipitation trends in Europe, December 1950 to February 2008. Climate Research, 72, 217-237. https://doi.org/10.3354/cr01467

Mann, H.B. (1945). Nonparametric tests against trend. Econometrica, 13, 245-259.

Maraun, D., Osborn, T.J., Gillett, N.P. (2008). United Kingdom daily precipitation intensity: improved early data, error estimates and an update from 2000 to 2006. Int. J.Climatol. 28, 833-842. https://doi.org/10.1002/ joc.1672.

Markonis, Y., Batelis, S. C., Dimakos, Y., Moschou, E., Koutsoyiannis, D. (2017). Temporal and spatial variability of rainfall over Greece. Theoretical and Applied Climatology, 130, 217-232.

Milentijević, N., Bačević, N., Ristić, D., Valjarević, A. Pantelić, M., Kićović, D. (2020). Application of Mann-Kendal (MK) test in trend analysis of air temperature and precipitation: case of Mačva district (Serbia). UNIVERSITY THOUGHT, Publication in Natural Sciences, Vol. 10, No. 1, 37-43. DOI: https://doi.org/10.5937/ univtho10-24774

Milivoj B. Gavrilov, B.M., Tošić, I., Marković, B.S., Unkašević, M., Petrović, P. (2016). Analysis of annual and seasonal temperature trends using the Mann-Kendall test in Vojvodina, Serbia. Időjárás, 120(2), 183-198.

Miloševic, D., Savic, S.(2013). Analysis of precipitation quantities and trends from Pannonian and Peripannonian parts of Serbia. Dela, 39, 125-139

Milošević, D., Savić, S.M., Stojanović, V., Popov-Raljić, J. (2015). Effects of precipitation and temperatures on crop yield variability in Vojvodina (Serbia). Italian Journal of agrometeorology, 20, 35-46.

Milošević, D.D., Savić, S.M., Pantelić, M., Stankov, U., Žiberna, I., Dolinaj, D., Leščešen, I. (2016). Variability of seasonal and annual precipitation in Slovenia and its correlation with large-scale atmospheric circulation. Open geosciences, 8(1), 593-605.

Milovanović. B. (2005). Statistical procedures application and results of research of precipitation on mountain Stara planina. Geographical institute "Jovan Cvijic" SASA collection of papers, 54, 33-44.

New, M., Todd, M., Hulme, M., Jones, P. (2001). Precipitation measurements and trends in the twentieth century. Int. J. Climatol., 21, 1889-1922. https://doi.org/10.1002/joc.680.

Nguyen, P. A., Thorstensen, S., Sorooshian, K., Hsu, A., Aghakouchak, H., Ashouri, H. T., Braithwaite, D. (2018). Global precipitation trends across spatial scales using satellite observations. Bulletin of the American Meteorological Society, 99, 689-697. DOI: https://doi.org/10.1175/BAMS-D-17-0065.1

Niedźwiedź, T., Twardosz, R., Walanus, A. (2009). Long-term variability of precipitation series in East central Europe in relation to circulation patterns. Theoret. Appl. Climatol. 98(3-4), 337-350. 
Nikolova, N. (2004). Rainfall Variability In Bulgaria And Its Relation With North Atlantic Oscillation. Ohrid, FY Republic of Macedonia, 25-29 May 2004.

O’Gorman, P.A. (2015). Precipitation extremes under climate change. Curr. Clim. Chang. Rep., 1, 49-59.

Oguntunde, P.G., Abiodun, B.J., Lischeid, G. (2011). Rainfall trends in Nigeria, 1901-2000. J Hydrol, 411, 207218

Philandras, C. M., Nastos, P. T., Kapsomenakis, J., Douvis, K. C., Tselioudis, G., Zerefos, C. S. (2011). Long term precipitation trends and variability within the Mediterranean region. Natural Hazards and Earth System Sciences, 11, 3235-3250.

Popov, T., Gnjato, S., Trbić, G. (2019). Analysis of extreme precipitation over the Peripannonian region of Bosnia and Hercegovina. Időjárás, 122(4), 433-452. doi:10.28974/idojaras.2018.4.5

Popov, T., Gnjato, S., Trbić, G. (2019). Changes in precipitation over the East Herzegovina region. Bulletin of the Serbian Geographical Society, 99(1), 29-44.

Radeva, K., Nikolova, N. (2020). Hydrometeorological Drought hazard and vulnerability assessment for Northern Bulgaria. Geographica Pannonica, 24(2), 112-123. DOI: 10.5937/gp24-25074

Savić, S., Kalfayan, M., Dolinaj, D. (2020). Precipitation spatial patterns in cities with different urbanisation types: Case study of Novi Sad (Serbia) as a medium-sized city. Geographica Pannonica, 24(2), 88-99.

Savić, S., Petrović, P., Milovanović, B. (2010). Homogenisation of mean air temperature data series from Serbia, EGU General Assembly 2010, Geophysical Research Abstract, vol. 12, EGU2010-5521-1.

Smith, T.M., Arkin, P.A., Ren, L., Shen, S.S. (2012). Improved reconstruction of global precipitation since 1900. J. Atmos. Ocean. Technol., 29, 1505-1517. https://doi.org/10.1175/JTECH-D-12-00001.1.

Spinoni, J., Naumann, G., Vogt, V. J. (2017). Pan-European seasonal trends and recent changes of drought frequency and severity. Global and Planetary Change, 148, 113-130.

Stojanović, G. (2012). Analiza godišnjih padavinskih suma na prostoru Srbije. J. Geogr. Inst. Cvijic, 62(2), 1-13.

Stojsavljevič, R., Savić, S., Milošević, D., Stojanov, S., Leščešen, I., Majstorović, V. (2013). Interpolation and Extrapolation of Precipitation Quantities in Serbia. European Researcher, 55(7-2), 1980-1986.

Tabari, H.,Hosseinzadeh Talaee, P. (2011). Temporal variability of precipitation over Iran: 1966-2005. Journal of Hydrology, 396(3-4), 313-320. https://doi.org/10.1016/j.jhydrol.2010.11.034

Tosic, I., Unkasevic, M. (2013). Extreme daily precipitation in Belgrade and their links with the prevailing directions of the air trajectories. Theor Appl Climatol, 111, 97-107.

Tošić, I. (2004). Spatial and temporal variability of winter and summer precipitation over Serbia and Montenegro. Theor. Appl. Climatol., 77, 47-56. DOI 10.1007/s00704-003-0022-7

Tošić, I., Unkašević, M. (2005). Analysis of precipitation series for Belgrade. Theor Appl Climatol, 80, 67-77.

Tošić, I., Zorn, M., Ortar, J., Unkašević, M., Gavrilov, M. B., Marković, S. B. (2016). Annual and seasonal variability of precipitation and temperatures in Slovenia from 1961 to 2011. Atmospheric Research, 168, 220233.

Unkašević, M., Tošić, I. (2011). A statistical analysis of the daily precipitation over Serbia: trends and indices. Theor Appl Climatol, 106, 69-78. DOI 10.1007/s00704-011-0418-8

van den Besselaar, E.J.M., Klein Tank, A.M.G., Buishand, T.A. (2013). Trends in European precipitation extremes over 1951-2010. Int. J. Climatol. 33, 2682-2689. https://doi.org/10.1002/joc.3619.

Villarini, G., Smith, J.A., Vecchi, G.A. (2013). Changing frequency of heavy rainfall over the Central United States. J. Clim., 26, 351-357. https://doi.org/10.1175/JCLI-D-12-00043.1.

Ye, H., Fetzer, E.J., Behrangi, A., Wong, S., Lambrigtsen, B.H., Wang, C.Y., Cohen, J., Gamelin, B.L. (2016). Increasing daily precipitation intensity associated with warmer air temperatures over Northern Eurasia. J. Clim. 29, 623-636. https://doi.org/10.1175//CLI-D-14-00771.1. 
CONFLICTS OF INTEREST The authors declared no potential conflicts of interest with respect to the research, authorship, and/or publication of this article. (c) 2021 by the authors. This article is an open access article distributed under the terms and conditions of the Creative Commons Attribution (CC BY) license (http://cre-ativecommons.org/licenses/by/4.0/).

ORCID Igor Leščěsen (1) https://orcid.org/0000-0001-9090-2662

Dragan Milošević (1) https://orcid.org/0000-0001-5050-0052

Rastislav Stojsavljević (1) https://orcid.org/0000-0002-4317-6765 